2. Уберман В. І., Васьковець Л. А. Поетапне наближення українського еколого-правового інституту якості вод та іiі регулювання до законодавства Європейського Союзу. Chap. in book: Legislation of EU countries: history, shortcomings and prospects for the development : Collective monograph. Frankfurt (Oder) : Izdevniecība «Baltija Publishing», 2019. P. 334-354. URL: https://core.ac.uk/download/pdf/304678851.pdf (дата звернення 25.01.2021).

3. Директива 2000/60/ЄС Європейського Парламенту і Ради «Про встановлення рамок діяльності Співтовариства в галузі водної політики» від 23 жовтня 2000 року. URL: https://zakon.rada.gov.ua/ laws/show/994_962\#Text (дата звернення 25.01.2021).

4. Угода про асоціацію між Україною, 3 однієї сторони, та Європейським Союзом, Європейським співтовариством 3 атомної енергії і їхніми державами-членами, 3 іншої сторони: Документ 984_011. Ред. від 30.11.2015. URL: https://zakon.rada.gov.ua/laws/ show/984_011 (дата звернення: 25.01.2021).

5. Подцерковний О. П. Загальні та спеціальні норми: проблеми виявлення та вирішення конкуренції. Вісник господарського судочинства. 2009. № 6. C. 34-43. URL: https://coordynata.com.ua/ zagalni-ta-specialni-normi-problemi-viavlenna-ta-virisenna-konkurencii (дата звернення: 25.01.2021).

DOI https://doi.org/10.30525/978-9934-26-040-7-63

\title{
ДО ПИТАННЯ ВІДПОВІДНОСТІ НОРМ НАЦІОНАЛЬНОГО ЗАКОНОДАВСТВА НОРМАМ МІЖНАРОДНОГО У СФЕРІ ПРОТИДІЇ ТА ЗАПОБІГАННЯ КОРУПЦІї
}

\author{
Щерба В. Ю. \\ магістр права, \\ уповноважена з антикорупиійної діяльності \\ Державної установи «Територіальне медичне об'єднання \\ Міністерства внутрішніх справ Украӥни по Вінниџькій області» \\ м. Вінниия, Украӥна
}

Ще від моменту створення першої держави корупція була «незмінною константою» у відносинах «держава-суспільство» та 
«держава-громадянин». Та лише на початку XX століття, коли почали створюватись перші міжнародні організації, питання боротьби 3 цим небезпечним для суспільства та держави явищем піднялось до міжнародного рівня.

Так, першим міжнародним документом в цьому напрямку стала резолюція Генеральної Асамблеї ООН 3514 (XXX) [1], що мала рекомендаційний характер та вказувала, що уряд кожної держави на власний розсуд та власними силами вживає всіх необхідних заходів для протидії та боротьби з корупцією. Наступним основоположним документом стали «Практичні заходи боротьби з корупцією» [2], які були ухвалені на VIII конгресі ООН 1990 року. Вказані заходи передбачають завдання для урядів щодо аналізу норм кримінального та кримінально-процесуального законодавства на предмет адекватної реакції на корупційні злочини; розробки адміністративних заходів попередження та профілактики скоєння корупційних правопорушень; розробки процедури виявлення, розслідування та притягнення до відповідальності посадових осіб; розробки правових догм про поводження 3 конфіскованими коштами та майном, отриманих в результаті корупційного правопорушення; застосування відповідних заходів впливу по відношенню до підприємств, причетних до корупції.

Від того часу завдання для боротьби 3 корупцією не змінились. «Практичні заходи боротьби з корупцією» знайшли свою деталізацію у наступних правових джерелах: резолюція Генеральної Асамблеї ООН «Боротьба $з$ корупцією» від 12 грудня 1996 року (A/RES/51/59), Декларація ООН «Про боротьбу з корупцією та хабарництвом в міжнародних комерційних операціях» (1996р.) [3], Міжнародний кодекс поведінки державних посадових осіб (1996р.) [4], Керуючі принципи для ефективного виконання Кодексу поведінки посадових осіб з підтримання правопорядку (1989 р).

Проте, як слушно зазначають дослідники права, глобальним антикорупційним документом стала Конвенція ООН проти корупції [5], прийнята на 58 сесії Генеральної Асамблеї ООН у жовтні 2003 року, яку Україна ратифікувала 18 жовтня 2006 року, а чинності вона набула 01 січня 2010 року. До своїх цілей Конвенція відносить: сприяння впровадження й посилення заходів, спрямованих на більш ефективне й дієве запобігання корупції та боротьбу з нею; заохочення, сприяння та підтримка міжнародного співробітництва й технічної допомоги в запобіганні корупції та в боротьбі з нею, зокрема в поверненні активів; заохочення чесності, відповідальності й належного управління громадськими справами й державним майном [5]. 
Україною успішно імплементовані положення Конвенції щодо: розробки і здійснення або застосування ефективної скоординованої політики протидії корупції, яка сприяє участі суспільства і відображає принципи правопорядку, належного управління державними справами й державним майном, чесності й непідкупності, прозорості й відповідальності; встановлення й заохочення ефективних видів практики, спрямованих на запобігання корупції, та прагнення періодично проводити оцінку відповідних правових інструментів; створення спеціального органу (органів), діяльність якого спрямована на запобігання i протидію корупції, активну участь громадськості у сфері запобігання корупції, створення кодексів поведінки службовців, зміцнення незалежності судової влади, закріплення кримінальної відповідальності за корупційні правопорушення та окреслення корупційних злочинів, встановлення відповідальності юридичних осіб.

Створюючи національну систему антикорупційних органів, в Україні враховано зарубіжні практики і запроваджено три відомі моделі спеціальних антикорупційних органів (багатоцільовий спеціалізований орган, наділений правоохоронними повноваженнями та превентивними функціями - НАБУ; орган протидії корупції в структурі діючого правоохоронного органу - Спеціалізована антикорупційна прокуратура у структурі Генеральної прокуратури України; інституції iз запобігання корупції, розроблення політики і координації дій Національне агентство з питань запобігання корупції), але при цьому обрано власний шлях, об'єднавши новостворені антикорупційні інституції з реформованими правоохоронними органами, зокрема, шляхом розподілу повноважень між НАБУ та ДБР в частині кримінального переслідування корупціонерів; залишення за прокуратурою координаційних та наглядових повноважень у сфері протидії корупції [6. с. 155]. Слід виокремити створення та запуск Вищого антикорупційного суду (далі - ВАКС) у 2019 році. Ефективність моделі, обраною Україною, уже демонструє свої переваги та недоліки. До переваг можна віднести покращення якості розслідування корупційних та пов'язаних 3 корупцією злочинів, що виражається не стільки у кількості відкритих проваджень, скільки у переданих справах до суду та притягнення винних осіб до відповідальності. Серед недоліків варто наголосити на законодавчих та функціональних обмеженнях повноважень спеціально утворених антикорупційних органів та, в деякій мірі, їх підконтрольності ЦОВВ, що призводить до ускладнень під час досудових розслідувань корупційних злочинів.

Ще одним об'ємним пластом у міжнародному антикорупційному законодавстві є нормативно-правові акти Ради Європи (далі - РЄ) в 250 
межах якої створений та функціонує спеціалізований антикорупційний орган за дотриманням антикорупційних стандартів у Державахчленах P€ - Група держав проти корупції (GRECO). Європейські стандарти у сфері протидії корупції включають: Кримінальну конвенцію про боротьбу з корупцією [7], Цивільну конвенцію про боротьбу 3 корупцією [8] та Додатковий протокол до Кримінальної конвенції про боротьбу з корупцією [9].

Україна $є$ підписантом вказаних актів та, відповідно, взяла на себе зобов'язання щодо реалізації ефективної антикорупційної політики, впровадження дієвого механізму протидії корупції. Європейська комісія за демократію через право (Венеціанська комісія), яка постійно дає оцінку законодавчим ініціативам України, зокрема і у антикорупційному законодавстві, серед своїх останніх висновків негативно оцінила рішення КСУ у справі обмеження повноважень НАЗК. Так, Венеціанська комісія зазначає, що «рішення №13-р/2020 Конституційного Суду України не має чітких аргументів, не є міцно заснованим на міжнародному праві, i, можливо, було заплямоване великим процесуальним недоліком - невирішеним питанням конфлікту інтересів деяких суддів» [10].

Отже, з огляду на вищезазначене, можна констатувати, що Україна послідовно останні кілька років впроваджує міжнародні стандарти боротьби із корупцією відповідно до взятих на себе зобов'язань. Проте, період становлення та налагодження процесів погодження та прийняття законодавчих актів у сфері протидії корупції, врегулювання відносин антикорупційних органів між собою та 3 іншими державними інституціями, питання відповідальності за корупційні та пов'язані 3 корупцією правопорушення досі тривають. Україні варто опиратись на міжнародний досвід та продовжувати більш детально регламентувати кожну сферу протидії корупції, адаптовувати національне законодавство відповідно до рекомендацій та висновків, наданих міжнародним співтовариством.

\section{Література:}

1. Меры против коррупции, практикуемой транснациональными и другими корпорациями, их посредниками и другими причастными к этому сторонами. Резолюція Генеральної Асамблеї ООН 3514 (XXX). [Електронний ресурс] - Режим доступу: https:/undocs.org/ru/A/RES/ $3514 \% 28 X X X \% 29$.

2. Попередження злочинності та кримінальне правосуддя у контексті розвитку: реалізації та перспективи міжнародного співробітництва. Практичні заходи боротьби з корупцією. [Електронний ресурс] Режим доступу: https://zakon.rada.gov.ua/laws/show/995_785\#Text. 
3. Декларація Організації Об'єднаних Націй про боротьбу 3 корупцією і хабарництвом у міжнародних комерційних операціях від 16 грудня 1996 року. / Міжнародні правові акти та законодавство окремих країн про корупцію. - К.: Школяр, 1999. // [Електронний pecypc]. - 2011. - Режим доступу: http://zakon2.rada.gov.ua.

4. Міжнародний кодекс поведінки державних посадових осіб від 23 липня 1996 року. // Міжнародні правові акти та законодавство окремих країн про корупцію. - К.: Школяр, 1999. // [Електронний pecypc]. - 2011. - Режим доступу: http://zakon1.rada.gov.ua.

5. Конвенція Організації Об'єднаних Націй проти корупції від 31 жовтня 2003 року. // Офіц. вісник України, 2006 року. - № 44. С. 10. - ст. 2938. // [Електронний ресурс]. - 2011. - Режим доступу: http://zakon.rada.gov.ua.

6. Ярмиш О. Спеціалізовані антикорупційні інституції: світовий досвід та національна модель / О. Ярмиш, Р. Мельник // Науковий часопис Національної академії прокуратури України. - 2015. № 2. - C. 144-155.

7. Кримінальна конвенція про боротьбу з корупцією (ETS 173) від 27 січня 1999 року. // Офіц. вісник України, 2006 р. - № 44. - с. 41. Ст. 2939.

8. Цивільна конвенція про боротьбу з корупцією від 4 листопада 1999 р. // Офіц. вісник України, 2006 року. - № 94. - С. 252. - Ст. 592.

9. Додатковий протокол до Кримінальної конвенції про боротьбу 3 корупцією (ETS 191) від 15 травня 2003 року. // Офіц. вісник України, 2006 p. - № 44. - С. 51. - Ст. 2940.

10. Терміновий спільний висновок Венеційської комісії щодо рішення КСУ №13-Р/2020. Висновок № 1012/2020. - Страсбург, 9 грудня 2020. - [Електронний ресурс]. - Режим доступу: https://unba.org.ua/assets/uploads/bddc77fbf7f0844888dd_file.pdf. 